\title{
Factors Affecting Business Development of Warung Tegal: The Case of Warung Tegal in Jabodetabek
}

\section{Tri Susanto ${ }^{1}$, Mirsa Diah Novianti ${ }^{2}$, Rene Johannes ${ }^{3}$, Holila Hatta ${ }^{4}$, Aurino Djamaris Rilman ${ }^{5}$ and Adi Budipriyanto ${ }^{6}$}

\author{
${ }^{1}$ Universitas Bakrie, Indonesia \\ ${ }^{2}$ Universitas Bakrie, Indonesia \\ ${ }^{3}$ Universitas Bakrie, Indonesia \\ ${ }^{4}$ Universitas Bakrie, Indonesia \\ ${ }^{5}$ Universitas Bakrie, Indonesia \\ ${ }^{6}$ Universitas Bakrie, Indonesia
}

\begin{abstract}
This study aims to identify the most important factors affecting business development of Warung Tegal in Jabodetabek. A method of Management Audits and Strategic Assumption Surfacing and Testing were used. Management audits resulted twenty-three factors influencing the business development of Warung Tegals. Strategies policies to support business development of Warung Tegal were identified, those are: procedures in management administration are not applied in accordance with the provisions, an assessment of employees based on the performance achieved and the provision of compensation is adjusted to the conditions agreed upon and felt by employees enough and has a positive effect on increasing productivity, and marketing contributes to the development of telecommunication business services, by offering a variety of food menus, diverse and interesting presentations, and an array that invites consumers to order food.
\end{abstract}

Keywords: Business Development, SAST, Warung Tegal, Audit Management

\section{Introduction}

Emerging economies like Indonesia, exemplify their daily economic activities with informality, yet they rapidly rising. The archipelago is greatly strengthening its economic and political position and Indonesia cities, like DKI Jakarta, become important nodes on the globe. Since the informal economy occupies a great deal of the city, Jabodetabek's informal economy comprises $\mathrm{xx} \%$ of the city's total economy (OECD 2017) - a particular attention on informal practices is justified. Moreover, the shadowing effect of the informal economy - which is substitutive to dependencies on a regulated capitalist mechanism contributes greatly to think alternatively on how the cities could work. While it is easily set aside as a natural phenomenon - informality is a composition of spontaneous and contingent events - there must be rules and norms, global or local, that are structurally integrated in the daily life of Jabodetabek.

In this research, the object of the informal sector is the warung tegal entrepreneurs. A warung provides food and drink and are typically represented in Javanese city streets. Warung Tegal (wateg) are incorporated in small restaurants. There are some 170.000 wartegs in Indonesia (Salahuddin Uno, 2011), They are mostly situated in the urban areas of the country and representative for Indonesian street life. Food and drinks can easily be consumed and thus play a significant role in the everyday lives of Javanese inhabitants, families, elderly, students and workers.

Warteg restaurants are unique in their setting since they are capable to combine divergent formal economic essentials with informal elements. Warteg restaurants offer an alternative perspective : they seem to be bigger in terms of revenues and accommodation, are less mobile since they are stuck to buildings or sites and unlike self-employed informal fellow entrepreneurs, have personnel. And besides their numerous presences, wartegs are literally able to provide the whole society of an essential need: food. 
Warung Tegal in Jabodetabek starts operations every day from morning to night, but not all have the same operating hours as the company's operating hours. Based on the results of a survey carried out on the Warteg in Jabodetabek, as can be seen in fig 1, the largest warteg operating hours are from 05.00 in the morning until 22.00 at night, which is around $30 \%$, followed by operating hours from $04.00-21.00$ at $26 \%$, after that, from $07.00-24.00$ at $22 \%$, this shows that the existence of the warteg to meet the needs of the community began in the morning until evening. However, it is possible that there are several regional offices that open operations throughout the night, because they utilize the needs of people who have never stopped.

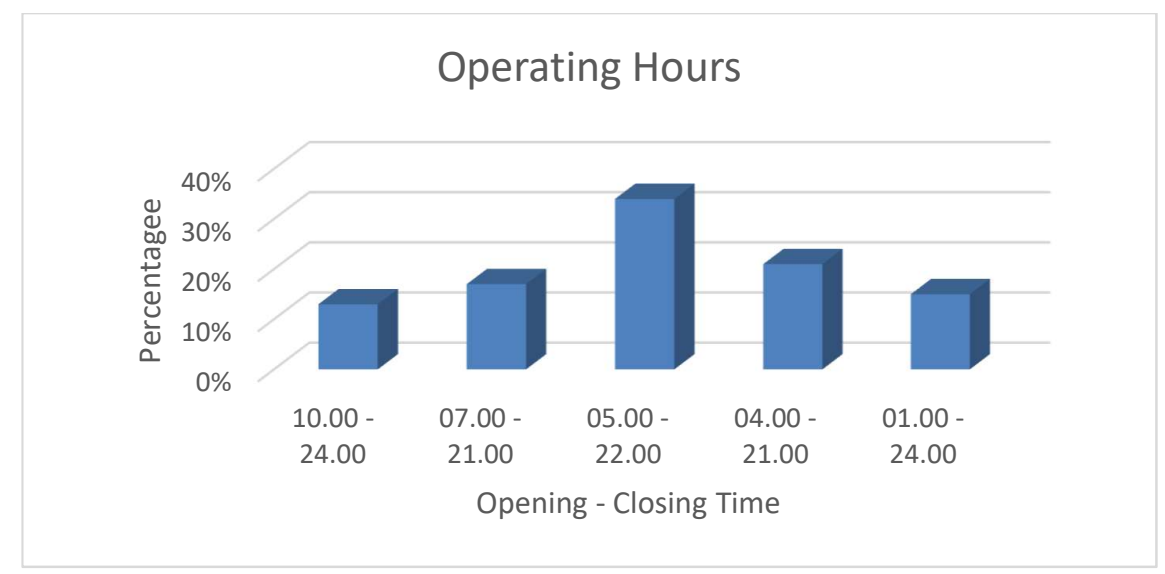

Figure 1. Operating hour of Warung Tegal

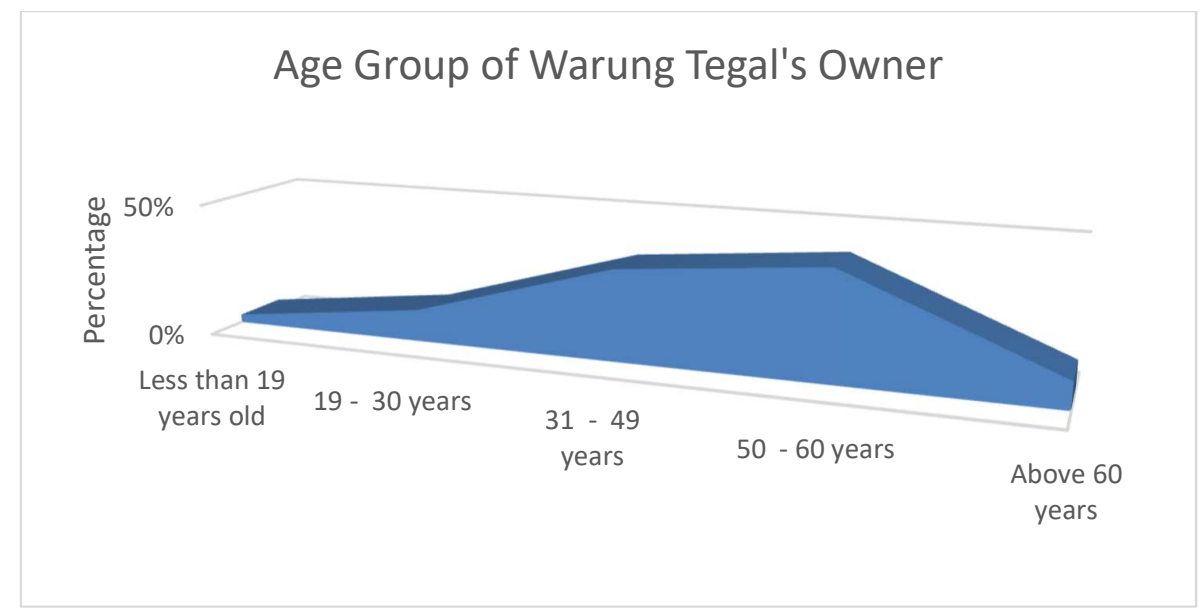

Figure 2. Age Group of Warung Tegal's owner

Warteg owners are depicted based on the survey results with the highest composition between 50 60 years old at $41 \%$, between 31 - 49 years old at $34 \%$, between 19 - 30 years old at $12 \%$ and the remaining young and elderly groups based on the description in fig 2. 


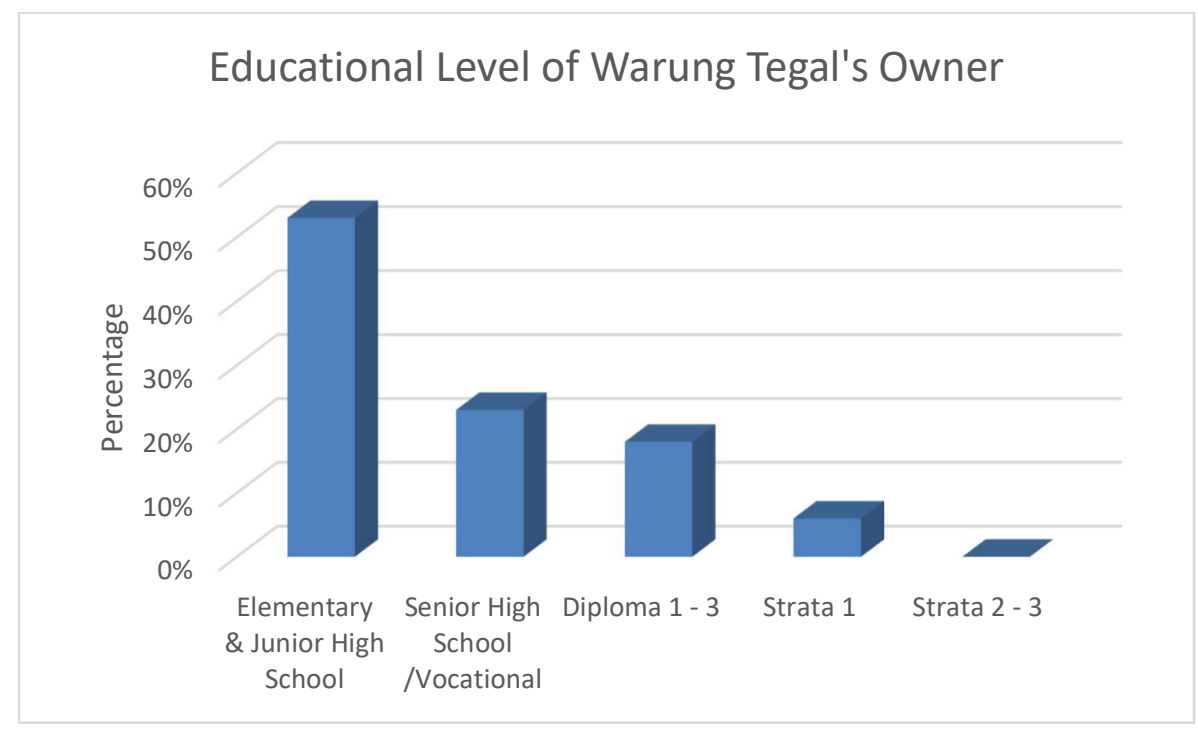

Figure 3. Educational level of Warteg owners

Most of the warteg owners' education level are elementary school and junior high school graduates, which is around 53\%, senior high school around $23 \%$, and while the rest are graduates of diploma or undergraduate degree. The tendency of business turnover to shrink, also lacking the courage of the owner to innovate and expand the market.

Monthly Sales Turnover (thousand rupiahs)

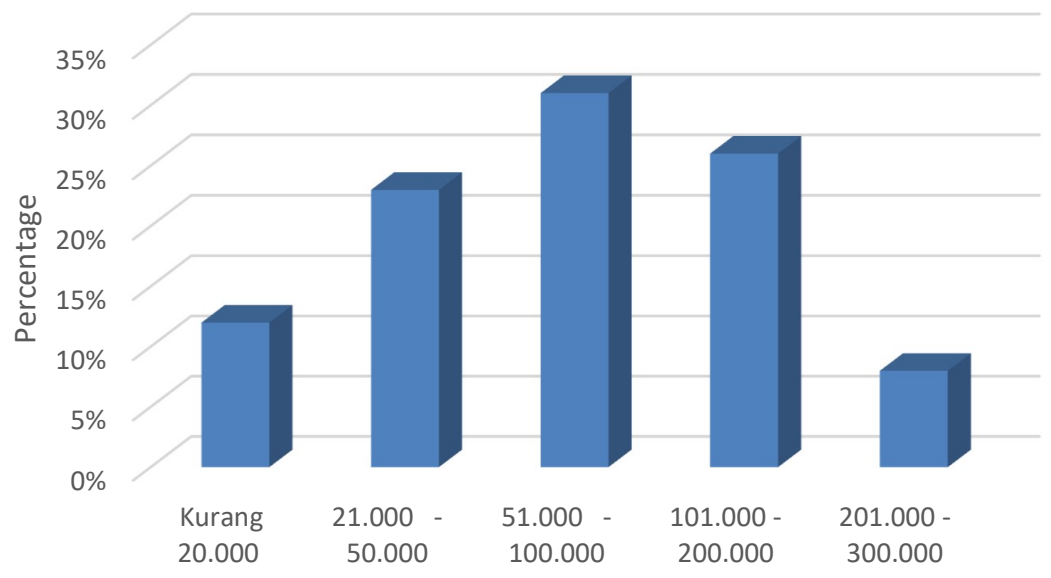

Figure 4. Monthly sales turnover

Turnover from sales from food businesses is quite promising, in one month it can reach 120 million rupiah or if converted in one day reaches 4 million rupiah. Based on the survey results on the sales of food and beverages in the Jabodetabek area, it is divided into several groups, such as the results of sellers around 51-100 million per month, around 31\%, for groups with sales of 101-200 million per month, around 26\%, while sales group $101-200$ million rupiah per month, around 26\% and group sales of 21-50 million rupiah per month, around $23 \%$. The description shows that opportunities for food business development have a high opportunity to develop, both in quality and quantity.

However, today the rise in economic activities and competition across the globe demands that the products and services offered by informal economy should be of best quality. The development of world has shown great interest in the possible contributions of informal economy in the social and 
economic development (as these industries now compete with their global peers. Informal economy sector is traditionally operating infer significant constraint such as financial constraints, nonfinancial constraints, skill human resources, and constraints relating to the enable environment.

Informal economy is a result of spontaneous urban development, and commonly is left untouched by the government. This is an issue that is triggering, since question marks can be placed at the intentions Indonesian governments have with the informal sector. When seeking answers for the question whether certain informal elements contribute to or stagnate the modernization of cities, we can discuss what the role of governance could and should be.

The role of informal economy in the process of modernization and economic growth should not be underestimated since informal economy covers a great part of life in Jabodetabek. By focusing on one substantial element in the Indonesian economy [I.e. warung entrepreneurs] this paper contributes to a better understanding of the informality in urban Java and to expose the informal elements that influence economic growth.

In an effort to increase the "degree" of SME products including Warteg, the DKI Jakarta Provincial Government has facilitated through a Governor Regulation which requires malls and retailers in Jakarta to provide as much as $20 \%$ minimum space for MSME products. Issuance of Minister of Trade Regulation number 70 of 2013 concerning Management of Traditional Markets, Modern Stores and Shopping Centers opens opportunities for good cooperation so that SME products can enter the mall. To provide the same benefits for mall owners, products that can enter the mall will be selected. In SMEs in general the skills possessed by employers and employees are mainly in making various kinds of products that can be said to be good. But talking about traditionally owned skill products (informal education) is not enough, special expertise is needed, which meets standards, including education based on formal education.

A management audit seeks to evaluate whether a company has a suitable management team in place to achieve its objectives. It includes a review of strategy, how it is being implemented and an evaluation of the profile and competencies of the management team. The scope of the management audit is to evaluate whether the organization has implemented right and adequate tools for achieving its strategy rather than simply checking that these tools are effectively working at an operational level (Lewington, 1991).

Strategic Assumption Surfacing and Testing (SAST) use a panel of expert to develop strategic assumptions. Questionnaire was distributed to experts whose competencies are related to important factors in determining policies in developing business. The principal of SAST model is participative, adversarial, integrative and managerial mind supporting (Mason \& Mittrof, 1981). Judgements or opinion of experts is positioned within 4 quadrans as shown in Fig. 5. According to its quadrant position, these opinions is used in defining alternative of strategic policy.

Therefore, this study wants to find out the driving factors for the improvement of Warung Tegal's business with the Management Audit and Strategic Assumption Surfacing and Testing approach in Jabodetabek.

\section{Research Methodology}

This research, in first phase, adopted questionnaire method as a mean for data collecting to examine the main factors affecting management audit. The design process is carried out in April - September 2018. This survey consists of the factors which might affect management audit. Respondents were selected based on the following 3 criteria:

1. The respondent represents the various functions of the Warteg business entity

2. Understand and control the management of food businesses,

3. Food business management experience not less than three (3) years.

Elements and Sub-Elements of the Management Audit Program can be seen in Table 1. These factors were used to prepare the self-assessment questionnaire, using the differential semantic scale. The results of calculating data from the questionnaire with the formula: 
$T k i=(X i / Y i) x 100 \%$

Where

Tki $=$ level of conformity,

$\mathrm{Xi}=$ average score of effectiveness, and

$\mathrm{Yi}=$ average level of importance score

Table1. Elements and Sub-Elements of the Management Audit Program

\begin{tabular}{|c|c|}
\hline Elements & Sub-Elements \\
\hline $\begin{array}{l}\text { 1. Stakeholders } \\
\text { affected }\end{array}$ & 1. Owner 2. Manager 3. Employee 4. Customer 5. Supplier \\
\hline $\begin{array}{l}\text { 2. Business entity } \\
\text { needs }\end{array}$ & $\begin{array}{l}\text { 1. As a material supply system } \\
\text { 2. Effective management implementation } \\
\text { 3. Support good governance to prevent risk to be more effective }\end{array}$ \\
\hline 3. The main obstacle & $\begin{array}{l}\text { 1. Commitment of the warteg owner } \\
\text { 2. Completeness and adequacy of operational device resources } \\
\text { 3. Stakeholder understanding of business management } \\
\text { 4. Knowledge and capabilities of users of the Management system } \\
\text { model } \\
\text { 5. Follow-up reports on Management results }\end{array}$ \\
\hline $\begin{array}{l}\text { 4. Desired internal } \\
\text { changes }\end{array}$ & $\begin{array}{l}\text { 1. Improved Management policies } \\
\text { 2. Increased effectiveness of Management } \\
\text { 3. Increased competence, capability and capacity of employee } \\
\text { performance }\end{array}$ \\
\hline 5. Objectives & $\begin{array}{l}\text { 1. Improved Management performance } \\
\text { 2. Increased overall organizational performance } \\
\text { 3. Improve management effectiveness } \\
\text { 4. Increasing the effectiveness of non-management functions } \\
\text { 5. Increasing the effectiveness of corporate culture }\end{array}$ \\
\hline $\begin{array}{l}\text { 6. Measurements for } \\
\text { assessing the } \\
\text { effectiveness of } \\
\text { each objective }\end{array}$ & $\begin{array}{l}\text { 1. The results of measurement of Management's performance / } \\
\text { effectiveness assessment } \\
\text { 2. Overall company productivity } \\
\text { 3. Perception of organizational actors on the quality of } \\
\text { Management } \\
\text { 4. Management audit report }\end{array}$ \\
\hline $\begin{array}{l}\text { 5. Institutions } \\
\text { involved }\end{array}$ & $\begin{array}{l}\text { 1. Warung Tegal } \\
\text { 2. Association of Warteg } \\
\text { 3. Auditors } \\
\text { 4. Mall Manager } \\
\text { 5. Related government agencies }\end{array}$ \\
\hline
\end{tabular}

Source: Data from Focus Group Discussion, August 30 ${ }^{\text {th }}, 2018$

At the next phased, based on four SAST principles consisting of Participative, Adversarial, Integrative and Managerial and mind supporting, four stages of the use of SAST techniques are developed, namely Group formation, Assumption surfacing, Dialectical debate, and Synthesis.

\section{Result and Discussion}

Respondents involved in the making of audit equipment consisted of eighty (80) warung tegal, which were spread in East Jakarta, Central Jakarta, South Jakarta, Bogor and Bekasi. The pilot sampling was conducted in May-August 2018, resulted twenty employees (27) employees represented various functions and levels such as cooks, shopping, serving and cleaning equipment. From the discussion 
of business entity culture, seven assumptions were obtained: (1) that the warteg must conform to business characteristics, (2) the warteg has distinctive characteristics that distinguish it from other culinary efforts, (3) (4) Warteg business must be formalized, (5) Warteg must be able to improve the quality of products presented, (6) understanding of the vision, and widely implemented (7) employees support business development.

Through the Group Discussion Forum (FGD), mapped 10 critical factors (Critical Success Factors / CSF) that affect the warteg namely:

(1) Assessment of Production \& Inventory capacity

(2) Raw Material Purchases \& Specifications,

(3) Control of Suppliers \& Production Facilities

(4) Quality Policy,

(5) Human Resource Development,

(6) Performance \& Compensation Assessment

(7) Marketing Valuation

(8) Process \& Display

(9) Tax Compliance

(10) Existence of Information \& Control Systems.

From this process, 23 assumptions of Management audit were obtained, namely:

1) The necessity of an owner's commitment,

2) As a managerial control tool,

3) As a system of providing data / information,

4) Is the process of examination, measurement and assessment

5) Prioritizing objectivity

6) Must be practical and applicable,

7) Is used for diagnosis and prognosis,

8) Involves owners, managers and employees,

9) Equipped with operational guidance,

10) A benchmark is used to assess effectiveness,

11) The competency of auditor

12) As directed at extracting value, preventing risks and ensuring compliance with principles

13) Aims to improve management effectiveness

14) Carried out with a self-assessment approach and / or a second party audit,

15) Corrective actions need to be verified,

16) Need guidance on writing audit reports,

17) Has a formal policy foundation,

18) Needs to be socialized,

19) Recording is carried out,

20) Need customization audit devices,

21) Preparation is required before the audit,

22) All activities are documented,

23) A management review is carried out

From these assumptions, all of the respondents are doing self-assessment questionnaire, using the differential semantic scale, and the results can be seen in Table 2 . 
Table 2. Comparison of Importance (Yi) values, Effectivity value (Xi) and suitability value

\begin{tabular}{|c|c|c|c|c|}
\hline \multirow{2}{*}{$\begin{array}{l}\text { Critical Success } \\
\text { Factors of } \\
\text { Warung Tegal }\end{array}$} & \multirow{2}{*}{$\begin{array}{l}\text { Explanation of critical factors affecting } \\
\text { Business Process }\end{array}$} & \multirow[b]{2}{*}{$\mathrm{Xi}$} & \multirow[b]{2}{*}{$\mathrm{Yi}$} & Tki \\
\hline & & & & $\%$ \\
\hline $\begin{array}{l}\text { Assessment of } \\
\text { Production \& } \\
\text { stock capacity }\end{array}$ & $\begin{array}{l}\text { Food processing activities are carried out in the } \\
\text { same amount, inventory control procedures, } \\
\text { maintenance schedules, daily evaluations }\end{array}$ & 1.21 & 3.13 & 38.66 \\
\hline $\begin{array}{l}\text { 2. Purchase } \\
\text { Control \& } \\
\text { Raw Material } \\
\text { Specifications }\end{array}$ & $\begin{array}{l}\text { Continuous training is held to strengthen the } \\
\text { culture of the business entity }\end{array}$ & 1.36 & 3 & 45.33 \\
\hline $\begin{array}{l}\text { 3. Supplier } \\
\text { Control \& } \\
\text { Production } \\
\text { Facilities }\end{array}$ & $\begin{array}{l}\text { Suppliers are evaluated the time and quality of } \\
\text { delivery, equipment in accordance with the } \\
\text { needs of effective and efficient, placement of } \\
\text { equipment in accordance with the needs of } \\
\text { equipment cleaned after use, }\end{array}$ & 2.00 & 3.35 & 59.70 \\
\hline 4. Quality Policy & $\begin{array}{l}\text { Policy on the quality of the food production } \\
\text { process in writing, handling storage of raw } \\
\text { material specifications and finished food, }\end{array}$ & 1.00 & 3.37 & 29.67 \\
\hline $\begin{array}{l}\text { 5. Human } \\
\text { Resources } \\
\text { Development }\end{array}$ & $\begin{array}{l}\text { Arranging planning involves employees, HR } \\
\text { planning considers the required qualifications, } \\
\text { training based on the evaluation results of } \\
\text { development needs }\end{array}$ & 1.35 & 3.03 & 44.55 \\
\hline $\begin{array}{l}\text { 6. Performance } \\
\& \\
\text { Compensation } \\
\text { Assessment }\end{array}$ & $\begin{array}{l}\text { Having a performance appraisal program, } \\
\text { valuation emphasizes performance achieved, } \\
\text { compensation provides satisfaction for } \\
\text { employees \& is given based on performance } \\
\text { evaluation }\end{array}$ & 3.25 & 3.2 & 101.56 \\
\hline $\begin{array}{l}\text { 7. Marketing } \\
\text { Evaluation }\end{array}$ & $\begin{array}{l}\text { Menu and taste of food according to customer } \\
\text { tastes, presentation of food and drinks neat and } \\
\text { clean, \& hygienic, interesting \& appetizing } \\
\text { food, varied food and beverage menu choices }\end{array}$ & 3.81 & 3.32 & 114.76 \\
\hline $\begin{array}{l}\text { 8. Process and } \\
\text { Display }\end{array}$ & $\begin{array}{l}\text { Have employees friendly \& polite, understand } \\
\text { all the menu information presented, respond to } \\
\text { consumer complaints quickly, order quickly } \\
\text { and precisely, payment is fast \& consistent }\end{array}$ & 2.82 & 3.33 & 84.68 \\
\hline $\begin{array}{l}\text { 9. Tax } \\
\text { Compliance }\end{array}$ & $\begin{array}{l}\text { As a taxpayer, do the bookkeeping or recording } \\
\text { properly, calculate the tax payable properly in } \\
\text { the period and annual tax return, deposit and } \\
\text { report the tax return period on time }\end{array}$ & 1.00 & 3.17 & 31.55 \\
\hline $\begin{array}{l}\text { 10. Existence of } \\
\text { Information \& } \\
\text { Control } \\
\text { Systems }\end{array}$ & $\begin{array}{l}\text { Having staff in experienced information } \\
\text { technology department, entering the relevant } \\
\text { numbers in the financial statements, including } \\
\text { the numbers of transactions in the financial } \\
\text { statements in full }\end{array}$ & 1.28 & 1.88 & 68.09 \\
\hline
\end{tabular}

The diagrammatic diagram of the warteg business development model can be explained by Figure 5 . Respondents were asked for opinions (opinion pooling) about the level of development of the warteg business, and the results showed that $20 \%$ of respondents argued for the business development of the 
warteg on performance evaluation and compensation and $80 \%$ of respondents at the symbolic level. Based on the data / information from the audit results, the company views the need to review the business development of the telecommunication company and plan an improvement program.

While the opinion survey of model users uses a Likert scale with questions containing 5 aspects: importance, usefulness, practicality, feasibility, recommendation with a five-level Likert scale (1-23-4-5), where one (1) shows lowest approval degree / weight and five (5) highest degree / approval weight, and three (3) are neutral. The survey results involving 27 respondents showed the following mean calculation data: importance: 3.8, usefulness: 4.3, practicality: 3.2, feasibility: 3, and recommendation: 4. This data shows relatively that the Management audit model of the design results is considered important, useful, practical, profitable, and recommended to be applied in the company.

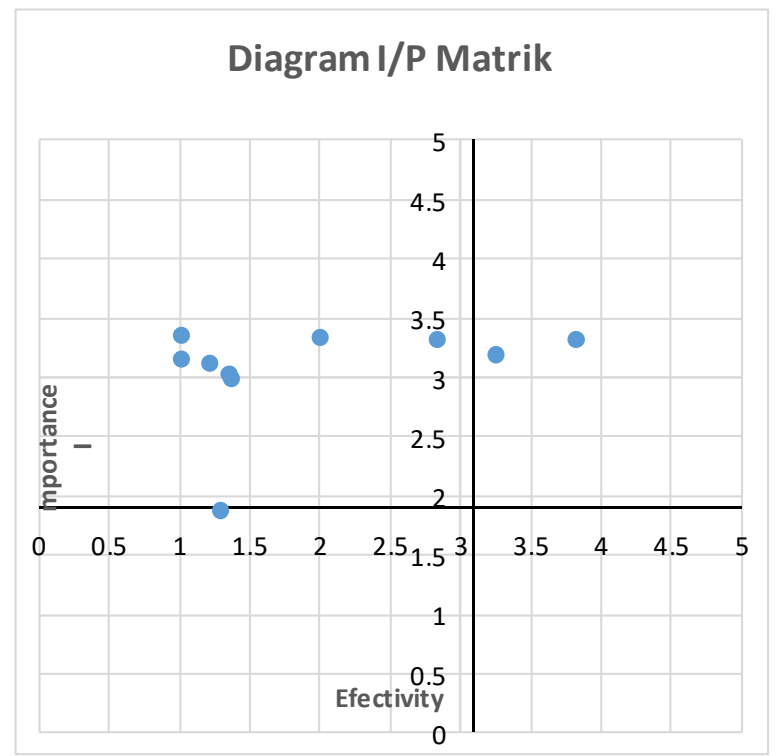

Figure 5. Matrix Importance Performance Diagram

Based on Figure 6, critical factors in quadrant I $(1,2,3,4,5,8.9,10)$ are considered important, but in reality they have not been effective, so it needs to be improved; factors in quadrant II (6.7) are considered important and have been implemented effectively, it needs to be maintained; critical factors in quadrant III (8) are considered less important and their implementation is also not very effective; this condition does not need to be a problem; factors in quadrant IV are seen as less important, but in reality they are carried out effectively. This condition is excessive, so it is not efficient, it needs improvement. 


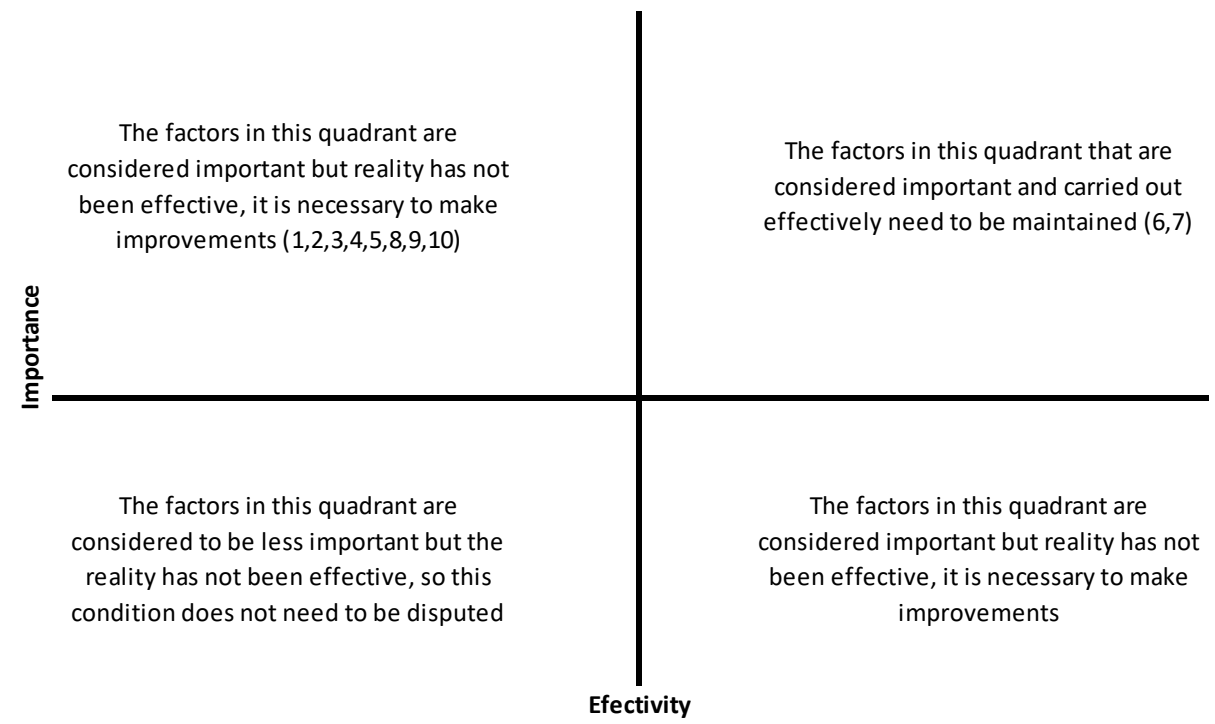

Figure 6. Importance Performance Analysis

\section{Conclusion}

The results of the trial show that the implementation of the management audit model has positive implications and the application can improve management functions more effectively and directed, besides this management audit model is seen as important, useful, practical, feasible and recommended to be applied in a small shop business.

As for some findings that demand improvement so that management activities are expected to be more effective and efficient are as follows:

1. Procedures in management administration are not applied in accordance with the provisions.

2. An assessment of employees based on the performance achieved and the provision of compensation is adjusted to the conditions agreed upon and felt by employees enough and has a positive effect on increasing productivity.

3. Marketing contributes to the development of telecommunication business services, by offering a variety of food menus, diverse and interesting presentations, and an array that invites consumers to order food.

Suggestion.

1. Activities to control food supplies need to be improved so as not to cause shortages or excesses.

2. Feeding material suppliers need to be evaluated, so that the delivery is correct in quantity, time and level of freshness, the condition of the cookware must be kept clean and the placement of improved arrangement.

3. In compiling the operational plan of the Warteg business, it is necessary to involve employees, in order to arrange it better and up-to-date and fulfill the needs of employees according to the qualifications needed.

4. In order to meet the development of the times, it is necessary to add employees who master information technology, in order to provide services that are fast, meticulous and a wider range.

\section{References}

Andi Suranta Meliala, Nazaruddin Matondang, Rahmi M Sari, Jurnal Optimasi Sistem Industri, Vol. 13 No. 2, April 2014:641- 664.

Arens dan Loebbecke. 2003. Auditing Pendekatan Terpadu. Edisi Indonesia. Penerbit Salemba Empat, Jakarta. 
Bertalanffy L. 1968. General System Theory: Foundations, development, application. New York: George Braziller.

Bursk, E.C. (1966) "View Your Customers As Investments", Harvard Business Review, May-June, Vol.44, pp91-94

CASL (1998) "Participant observation and individual interviews", http://iisd.ca/casl/CASLGuide/ParticipantObserver.htm

Clackworthy, S. (2000) "The value of reporting in the information age", ManagementAccounting,(UK), March, Vol.78, No.3, pp38-39.

Dale, L. Flesher and Stewart Siewert.1982. Independent auditor's guide to operational Auditing. New York: John Wiley and Sons

Davenport, T.H., and Prusak, L. (1998) Working Knowledge, How Organizations Manage What They Know, Harvard Business School Press, Boston, Massachusetts.

Eccles, R.G., Nohria, N., and Berkley, J.D. (1992) Beyond the Hype, Rediscovering the Essence of Management, Harvard Business School Press, Boston, Massachusetts

Guthrie, J. and Petty, R. (2000 (a)) "No accounting for taste", Management Today, March, Australian Institute of Management, pp21-23

Guthrie, J. and Petty, R. (2000 (b)) “Are companies Thinking Smart?”, Australian CPA, July, pp6265 (http://www.republika.co.id/berita/koran/urbana/15/04-/16/nmw94g16-sedap-merakyatdiaspora-warteg-di-ibu-kota).

(http://www.kompasiana.com/sujadi/mimpi-bisnis-di-balik-warteg_55ff34d93cafbdf90ee7bdd94)

Jafar Hafsah (2004)Pengembangan kemitraan usaha besar dan kecil serta SDM, Infokop Nomor 25 Tahun XX.

Jackson, M. C. 2003. System Thinking: Creative Holism for Managers”. John Wiley \& Sons, New York.

Leslie R. Howard (1978), Auditing, Bungay,Great Britain, Richard Clay Ltd. Sixth Edition

Lowrence B Sawyer, Mortimer A Dittenhofer, James H. Schiener, Sawyer's Internal Auditing, salembat Empat, Jakarta 2015.

Malone, D.W. 1975. An introduction to the application of interpretative structural modeling, proceeding of the IEEE, vol.62 No.3, pp.397-404.

Mason, R.O., and Mitroff, I.I., 1981; "Challenging Strategic Planning Assumptions:Theory,Cases and Techniques", NY, Wiley, ISBN 0-471-08219-8

Nur Fathonah Sadek, 2010, Departemen Ilmu dan Teknologi Pangan Fakultas Teknologi Pertanian Institut Pertanian Bogor.

Niemark, M.K. (1995) The Hidden Dimensions of Annual Reports, Sixty years of Social Conflict at General Motors, Markus Wiener, Princeton, New Jersey

Reilly, R.F. and Dandekar, M.P. (1997) "Valuation of intangible rights", The CPA Journal, New York, June, Vol.67, Issue 6, pp74-75

Rivette, K.G. and Kline, D. (2000) "Discovering New Value in Intellectual Property", Harvard Business Review, January-February, Vol.78, No.1, pp54-66

Saxena, J.P. et al. 1992. Hierarchy and Classification of Program Plan Element Using Interpretative Structural Modelling. Systems Practice, 12 (6), 651:670.

Situmorang, 2008, Kemudahan mendapatkan perijinan dan akses kredit, Infokop Vplume 16 September 2008, pp 87-101

Subbarao, A.V. and Zeghal, D. (1997) "Human Resources Information Disclosure inAnnual Reports: An International Comparison", Journal of Human Resource Costingand Accounting, Autumn, Vol.2, No.2, pp 53-73

Sudaryanto, Ragimun dan Rahma Rina Wijayanti, 2013, Strategi Pemberdayaan UMKM Menghadapi Pasar Bebas Asean, Kemenkeu.

Sugiyono.(2013). Metode Penelitian Kuantitatif Kualitatif dan R\&D. Bandung : Penerbit Alfabeta 
Wianarni (2006). Adanya penjaminan kredit, UKM menjadi bankable , InfokopNomor29 Tahun XXII, 2006 